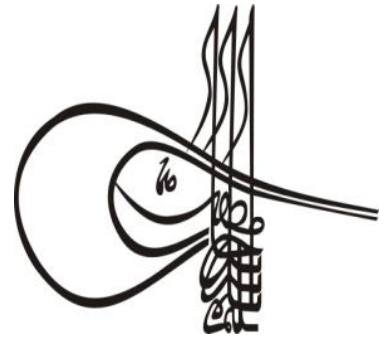

Received/Geliş: 06.03.2019

\section{Turkigh Studies \\ Social Sciences}

Volume 14 Issue 4, 2019, p. 1759-1774

DOI: 10.29228/TurkishStudies.22807

ISSN: 2667-5617

Skopje/MACEDONIA-Ankara/TURKEY

Research Article / Araştırma Makalesi

Article Info/Makale Bilgisi

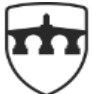

INTERNATIONAL BALKAN UNIVERSITY

EXCELLENCE FOR THE FUTURE IBU.EDU.MK

\Accepted/Kabul: 10.08.2019

Gor Report Dates/Rapor Tarihleri: Referee 1 (03.04.2019)-Referee 2 (14.03.2019)

This article was checked by iThenticate.

\title{
GÜMÜŞ TÜMÜLÜSÜ (BİZANS DÖNEMİ) TOPLUMUNDA Dİş SAĞLIĞI
}

\author{
Ayşegül ŞARBAK*
}

\begin{abstract}
öz
Dişler üzerinde yapılan incelemeler, arkeolojik toplumların beslenmesi, sağlık yapıs1, yaşı, cinsiyeti, diğer toplumlarla olan akrabalık ilişkileri ve kültürel alışkanlıklarının aydınlatılmasında önemli veriler sunmaktadır. Çalışmanın materyalini oluşturan dişler, Bizans Dönemi'ne tarihlendirilen Gümüş Tümülüsü toplumuna aittir. Gümüş Tümülüsü Karabük ili Safranbolu ilçesi, Erenler Tepesi Mevkii'nde bulunmaktadır. Çalışmanın amacı Bizans Dönemine tarihlendirilen Gümüş Tümülüsü toplumunun dişlerini paleopatolojik açıdan inceleyerek sosyo-ekonomik durumu, sağlık yapısı ve beslenme biçimlerini belirlemektir. Ayrıca diş patolojileri açısından çağdaşı olan diğer eski Anadolu toplumları arasındaki yerini belirlemektir. Bu doğrultuda Gümüş Tümülüsü kazılarından ele geçirilen 24 bireye ait 282 diş paleopatolojik açıdan incelenmiştir. 282 dişin 139'u kadın, 73'ü erkek, 38'i çocuk ve 15 ’ adölesan bireye aittir. 17 diş ise izoledir. Yapılan incelemeler sonucunda toplumda diş çürüğü oran1 \% 3,52 olarak bulunmuştur. Gümüş Tümülüsü diş çürüğü oranı kadınlarda $\% 4,76$ iken erkek bireylerde \%1,69'dur. Çocuklarda diş çürüğü oranı $\% 5,26$ olarak tespit edilmiştir. Adölesan bireyin dişlerinde ise çürük gözlenmemiştir. Diş sağlığının en önemli göstergelerinden biri olan apse oranı ise \%1,4 olarak tespit edilmiştir. Antemortem diş kaybı oranı ise $\% 6,2$ 'dir. Antemortem diş kaybı oranı kadın bireylerde \%5,31 iken, erkek bireylerde $\% 7,84$ olarak belirlenmiștir. Toplumun gerek beslenme yapıs1, besin hazırlama biçimi gerekse ağız sağlığı hakkında önemli ipuçları sunan diş taşı oranı ise \%17,34 olarak belirlenmiştir. Toplumun diş aşınması ise ileri derecedir.
\end{abstract}

Anahtar Kelimeler: Gümüş Tümülüsü, Bizans, Diş Sağlığı, Patoloji, Anadolu 


\title{
TEETH HEALTH OF GUMUS TUMULUS POPULATION (THE BYZANTINE PERIOD)
}

\begin{abstract}
The examinations on the teeth provide important data on the nutrition of the archaeological societies, the health structure, age, sex, relationship between the other populations and their cultural habits. The teeth forming the study material belong to the Gumus Tumulus population dated to the Byzantine Period. Gumus Tumulus is located in Erenler Tepesi Mevkii, Safranbolu, Karabük. The aim of the study is to determine the socio-economic status, health structure and feeding patterns of the Gumus Tumulus population, which are dated to the Byzantine period, by examining the teeth of the Gumus Tumulus population. It is also to determine the place among the other ancient Anatolian populations which are contemporary in terms of dental pathologies. In this respect, 282 teeth of 24 individuals from the GumusTumulus excavations were examined from a paleopathological point of view. Of the 282 teeth, 139 belong to the female individual, 73 to the male individual, 38 to the child and 15 to the adolescent individual. 17 teeth are isolated. As a result of the examinations, teeth caries rate in the population is found to be $3.52 \%$. The Gumus Tumulus rate of teeth caries is $4.76 \%$ for female and $1.69 \%$ for male. The rate of dental caries in children is $5.26 \%$. There is no dental caries in the teeth of the adolescent. The rate of abscess, which is one of the most important indicators of dental health, is determined as $1.4 \%$. Antemortem tooth loss rate is $6.2 \%$. Antemortem tooth loss rate is found to be $5.31 \%$ in female and $7.84 \%$ in male subjects. The rate of dental stones, which provide important clues about the nutritional structure, nutrient preparation and oral health of the society, is determined as $17.34 \%$. Population's teeth wear is 4 degrees.
\end{abstract}

\section{STRUCTURED ABSTRACT}

Gümüş Tumulus that is dated to the Byzantine Period, is located in Erenler Tepesi, town of Safranbolu, Karabuk province. The paleoanthropological analysis of human skeletal remains that were excavated from excavation of the Gümüş Tumulus was carried out in at Department of Anthropology, Faculty of Arts and Sciences, Hitit University. The skeletons that are examined were firstly cleaned and repaired and then the sex and age of each individual were determined (Olivier, 1969; Workshop of European Anthropologist, 1980; Brothwell, 1981; Kaur ve Jit, 1990; Buikstra ve Ubelaker, 1994; White vd, 2012).The criteria that is determined by White et al. (2012) were used to determine age ranges. As a result of the analyzes, a total of 24 individuals were identified in the Gümüş Tumulus. Of the 24 individuals, $12(50 \%)$ belonged to female individuals, $8(33.33 \%)$ were male, $3(12.5 \%)$ belonged to children, and $1(4.16 \%)$ belonged to the adolescent individual (Çrak et al, 2017). When the age distribution in the poplation is examined, it is seen that $16.7 \%$ of them are young adults, $35.7 \%$ of them are middle adults and $29.1 \%$ of them are old adult individuals (Graphic2) (Çırak et al., 2017). 
A total of 282 permanent teeth that are excavated from the population of Gümüş Tumulus were investigated in terms of odontological. It was determined that the teeth belonged to 139 female, 73 male, 38 child and 15 adolescent. 17 of the teeth is isolated. There are pathologies in the teeth of the Gümüs Tumulus; tooth caries (Buikstra and Ubelaker, 1994; Caselitz, 1998), dental calculus (Brothwell,1981), tooth wear (Brothwell, 1981; Ubelaker, 1978), alveolar bone loss (Brothwell,1981), abscess (Brothwell, 1981) were examined. Antemortem tooth loss is processed into the form as yes / no. The teeth could not be evaluated for hypoplasia because of the teeth have damage on the enamel layers. The pathologies that are seen on the teeth were examined according to the tooth groups. The rate of dental caries was $3.52 \%$, antemortem tooth loss was $6.2 \%$ and abscess rate was $1.4 \%$. The pathologies that are observed in the teeth of the Gümüş Tumulus were evaluated in terms of sex (Table 8). According to this, tooth caries was $4.76 \%$ in female and $1.7 \%$ in male individuals. Researchers stated that the incidence of tooth caries is different between sexes and that females are more affected by tooth caries (Larsen et al., 1991; Vanna, 2007;). The reasons of the higher incidence of dental caries in female individuals are that girls have earlier teeth, physical and behavioral differences between sexes and the negative effects of pregnancy on dental health (Larsen et al., 1991; 194). In addition, hormonal changes that are seen in females are also effective in the formation of dental caries (Vanna, 2007). In the Gümüş Tumulus population, it is thought that these factors may be effective in high rate of tooth caries in females. The rate of alveolar loss was found to be $60.16 \%$ in female individuals and $63 \%$ in male individuals. Antemortem tooth loss and dental calculus rates are higher in male individuals. The ratio of abscess is close to both sexes. In the Gümüss Tumulus population, the rate of tooth wear is as high as $78.02 \%$. When the distribution of the rate of tooth wear is considered, it is seen that the ratio is highest $(18.43 \%)$ as the 4 th degree. In addition, the high abrasion rate of the pulp makes think that hard particles may be mixed into the food. It is known that the rate of tooth caries is higher in the old Anatolian societies where intensive agricultural activities are performed. The low incidence of dental caries in the Gümüş Tumulus population indicates that there is no intensive agricultural activity in the population. It is known that high rates of carbohydrate comsumption and severe abrasion are caused to the abscess.

While the rate of dental caries in the Gümüş Tumulus population is low, the rate of abrasion is high as $78.02 \%$, indicating that abrasion may be among the causes of abscess. It is seen that individuals with severe alveolar bone loss are old adult individuals in the Gümüş Tumulus population. Therefore, it may be thought that the alveolar loss which is in the Gümüş Tumulus is related to age. Causes of antemortem tooth loss include dental caries, severe dental wear, dental calculus and alveolar bone loss. In the Gümüş Tumulus population, if it is thought the rate of alveol bone loss and wear is high, although the rate of dental caries is low, the causes of antemortem include alveolar bone loss and dental wear can be shown. When the age distribution of the individuals who have antemortem teeth loss is examined, it is determined that the old adult individuals are in the majority. The dental pathologies that are belonging to the Gümüş Tumulus population have 
been compared with other ancient Anatolian societies which are contemporary. When the ratio of dental caries that are belonging to Gümüş Tumulus compare with contemporary populations, it is observed that it has the lowest rate after the Laodikeia population (Simssek, 2011). In terms of abscess rate, it is seen that it has the same rate with Amasya (Akbacak and Gözlük Kırmızıoglu, 2018), Hellenistic Period Smyrna Agora (Yasar et al., 2007), Roman Period Domanic (Erkman et al., 2017), Byzantine Period Smyrna Agora (Gözlük et al., 2005) (Table 9). The rate of dental calculus are belonging to Gümüş Tumulus has close values with the population of Panaztepe and Smyrna Agora. The abscess has rate that is as low as the dental caries rate in the Gümüş Tumulus population (Table 9). While the rate of abscess has higher rate than the population of Datça / Burgaz (Karaöz Arıhan et al., 2009), Amasya, Kyzikos (Gözlük Kırmızıŏlu et al., 2008), Çiçekdağ1 (Alkan et al.,2013), it has lower rate than the societies of Milas / Gümüşlük (Sağır et al., 2009), Laodikeia, Arslantepe (Uzel et al. (1987), Dara Antique City (Şarbak, 2017), Kirazlıdere (Suata Alpaslan and Uz, 2017), Alanya Castle (Üstundag and Demirel, 2009), Iasos (Y1lmaz Usta, 2013), Zeytinli Ada (Bıçak and Suata Alpaslan, 2015), Mardin / Midyat (Acar, 2018) (Table 9). While the rate of alveolar bone loss in the Gümüş Tumulus population is similar to Dara Ancient City, it has higher rate in the populaiton of Çiçekdağı, Alanya Castle, Smyrna Agora, Datça / Burgaz, Parion (Yavuz et al., 2012), Laodikeia, Kirazlidere, Amasya (Table 9). Kyzikos (Gözlük Kırmızıoglu et al., 2008) and Iasos populations have a low rate (Table 9). In Byzantine Gümüss Tumulus population, the degree of dental wear was 4 . When this value compare with contemporary population, it is similar to the population has economy that is agricultural and livestock farming. As a result, it can be said that besides the agricultural products, proteins are included in the nutrition of the Gümüş Tumulus population. When dental caries and abscess rates, which provide important data about oral and dental health, are lower, the population's dental health and socioeconomic levels are considered to be good. Anatolia

Keywords: Gümüş Tumulusu, Byzatine, Teeth Health, Pathology,

\section{Giriş}

Dişler tüm iskelet materyaller içinde kimyasal ve fiziksel tahribata en dirençli olanıdır (White vd,2012). Dolayısıyla arkeolojik ve paleontolojik kazı çalışmalarında en çok ele geçirilen materyallerdir. Dişler milyonlarca önce yaşamış olan canlıların tür tayinlerinin yapılmasını ve onların yaşamış oldukları ekolojik bilgilerin elde edilmesini sağladıkları gibi antik dönemde yaşamış olan insanların yaş, cinsiyet, sağlık, diyet, kültürel alışkanlıklarının yanı sıra toplumlar arası genetik yakınlık gibi bir çok bilgiyi sunmaktadır (White vd,2012; Roberts ve Manchester 2012). Dişler besini yakalama, tutma ve çiğneme görevinden dolayı fiziksel çevre ile direkt ilişkili olduklarından dolayı çevresel etmenlere karşı da oldukça hassastır. Yiyecek türü ağızda bulunan mikro organizmaları belirler ve bir kişinin dişlerinin durumu, o dişlerle temas eden yiyeceğin bileşimini yansıtabilir (Roberts ve Manchester 2012). Diş patolojileri arkeolojik toplumlarda en s1k görülen patolojik oluşumlardır (Hillson,2008). Diş patolojileri dejerenatif ve gelişimsel patolojiler olmak üzere iki başlık altında incelenir (Roberts ve Manchester 2012). Diş çürügü̈, antemortem diş kaybı ve alveol kemik kaybı dejerenatif patolojiler arasında yer alırken, hipoplasya, diş eksikliği ya da fazlalığı genetik kökenli anomaliler gelişimsel patolojiler arasında yer almaktadır. Dişlerde görülen patolojiler 
toplumların yaşadıkları döneme, bölgeye ve sahip oldukları kültüre göre değişiklik göstermektedir. Dolayısıyla dişlerin incelenmesiyle birlikte antik dönem toplumların biyo-kültürel yapıları ortaya çıkarılmaktadır. Dişılerin makroskobik ya da mikroskobik incelenmeleri toplumların diyetleri hakkında önemli bilgiler sunmaktadır. Örneğin dişler üzerinde yapılan izotop analizleri ve mikro aşınma çalışmaları toplumların paleodiyetlerinin ortaya çıkarılmasını sağlamaktadır. Ayrıca dişler üzerinde yapılan metrik ve non-metrik incelemeler toplumlar arasındaki biyolojik uzaklıkların belirlenmesine katkı sağlamaktadır.

Çalışmanın amacı Bizans Dönemine tarihlendirilen Gümüş Tümülüsü toplumunun dişlerini paleopatolojik açıdan inceleyerek sosyo-ekonomik durumu, sağlık yapısı ve beslenme biçimlerini belirlemek ve diş patolojileri açısından çağdaşı olan Eski Anadolu toplumları arasındaki yerini belirlemektir.

\section{Materyal-Metot}

Gümüş Tümülüsü, Karabük ili Safranbolu ilçesi, Erenler Tepesi Mevkiinde yer almaktadır (Harita 1). Tümülüs'te, 31.10.2011 tarihinde kazı çalışmalara başlanmış ve 2013 ve 2014 yıllarında periyodlar halinde kurtarma kazıları devam ettirilmiştir (Resim 1). Tümülüs üzerinde farklı noktalarda toplamda 4 farklı açmada kazı çalışmaları yürütülmüştür. M.Ö. IV. yy. a ait olduğunu düşünülen Tümülüs kazı çalışmaları İstanbul Üniversitesi Öğretim Üyesi Dr. Öğr. Üyesi Ahmet Fethi YÜKSEL'in ve ekip çalışanlarının uzmanlığında, Doç. Dr. Şahin YILDIRIM denetiminde gerçekleştirilmiştir.

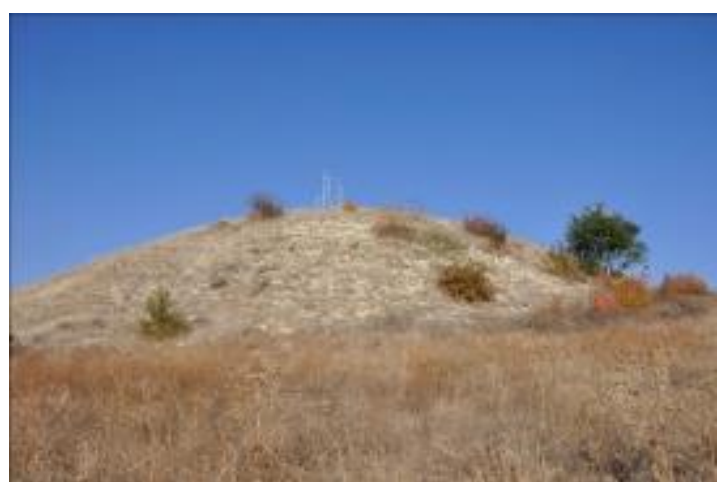

Resim 1.Gümüş Tümülüsü

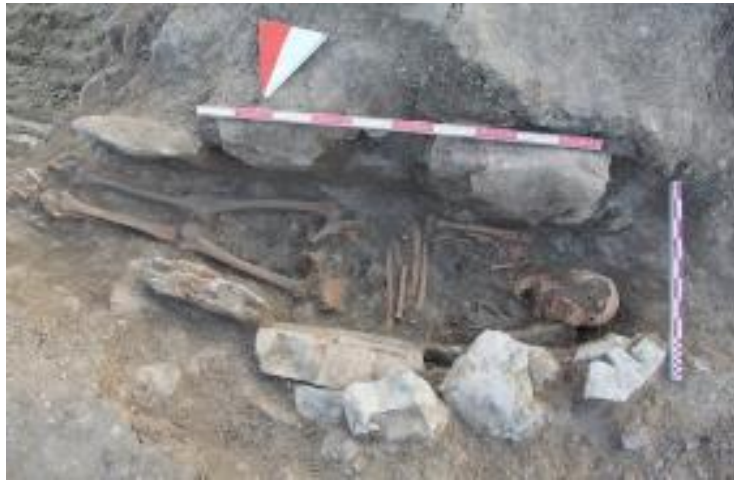

Resim 2. 16 No.lu Mezar

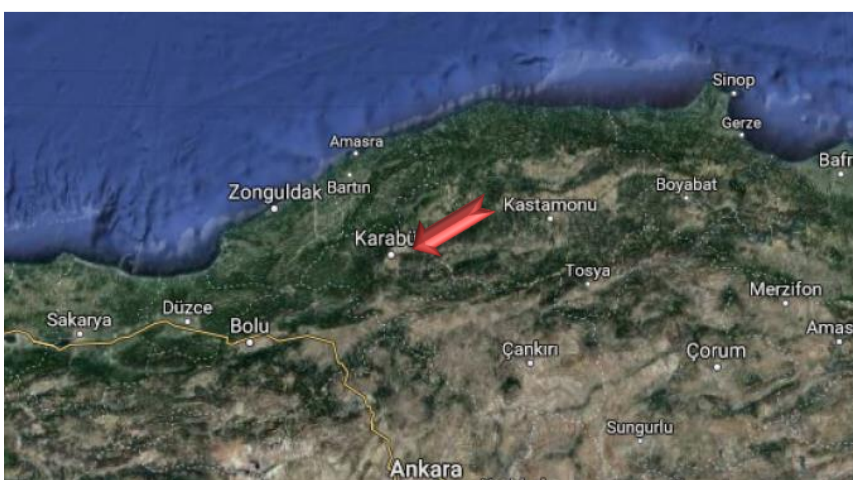

Harita 1. Gümüş Tümülüsü

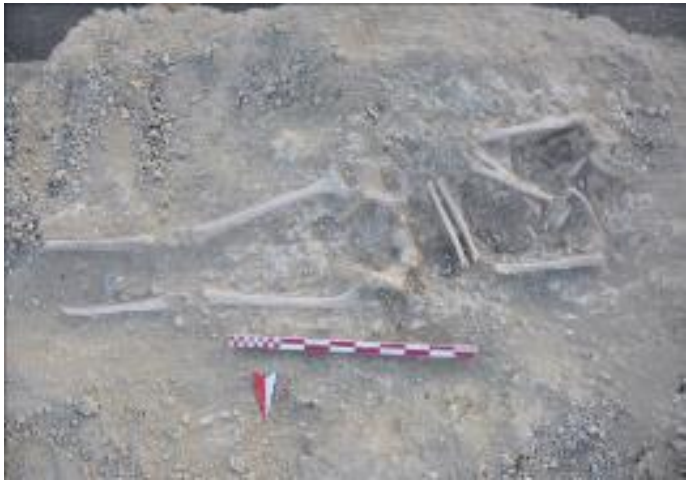

Resim 3. 5 No.lu Mezar

Tümülüs'ün tepe noktasında yüzeye yakın alandan toplamda 17 adet mezar tespit edilmiștir. Mezarların hepsi Bizans Dönemi'ne ait olup mezarlar arasında yön birliği bulunmaktadır (Resim 2-3). 
Gümüş Tümülüsü kazı çalışmaları sırasında çıkarılan insan iskelet kalıntılarının paleoantropolojik analizi Hitit Üniversitesi, Fen-Edebiyat Fakültesi, Antropoloji Bölümü laboratuvarında gerçekleştirilmiştir. İncelenmeye alınan iskeletlerin öncelikle temizlik ve onarımları yapılmış daha sonra her bireyin cinsiyet ve yaşı belirlenmiştir (Olivier, 1969; Workshop of European Anthropologist 1980; Brothwell, 1981; Kaur ve Jit, 1990; Buikstra ve Ubelaker,1994; White vd, 2012). Yaş aralıklarının belirlenmesinde ise White ve arkadaşlarının (2012) belirlediği kriterler kullanılmıştır. Yapılan analizler sonucunda Gümüş Tümülüsü'nde toplam 24 birey tespit edilmiştir. 24 bireyden 12'si (\%50) kadın bireylere, 8'i $(\% 33,33)$ erkek bireylere, 3'ü $(\% 12,5)$ çocuklara, 1'(\%4,16) ise adölesan bireye ait olduğu belirlenmiştir (Çırak vd,2017).

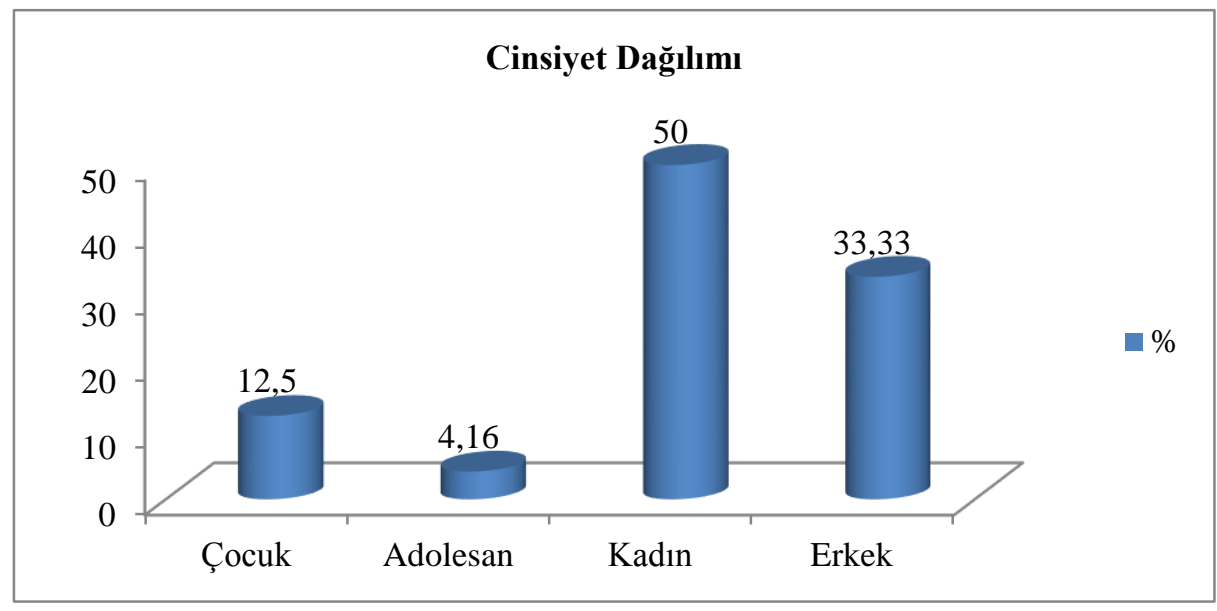

Grafik 1. Gümüş Tümülüsü Toplumunun Cinsiyet Dağılımı

Toplumdaki yaş dağılımına bakıldığında ise \%16,7'sinin genç erişkin, \%35,7'sinin orta erişkin, \%29,1'nin ise ileri erişkin bireylerden oluştuğu görülmektedir (Grafik 2) (Çırak vd,2017).

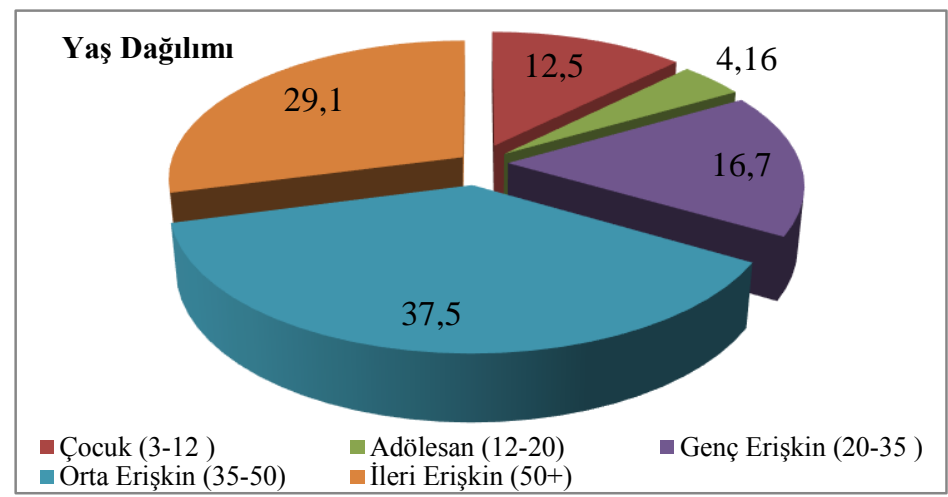

* Yaş grupları; Bebek (0-3 Yaş); Çocuk (3-12 yaş); Adölesan (12-20 yaş); Genç Erişkin (20-35 yaş); Orta Erişkin (35-50 yaş); Ileri Erişkin (50+) olarak ele alınmıştır (White,2012).

Grafik 2. Gümüş Tümülüsü Toplumunun Yaş Dağılımı

Gümüş Tümülüsü Toplumuna ait toplam kalıcı 282 diş odontolojik açidan incelenmiştir. Dişlerin 139'u kadın birey, 73'ü erkek birey, 38'i çocuk, 15'i adölesan bireye ait olduğu belirlenmiştir. Dişlerin 17'si ise izoledir. 


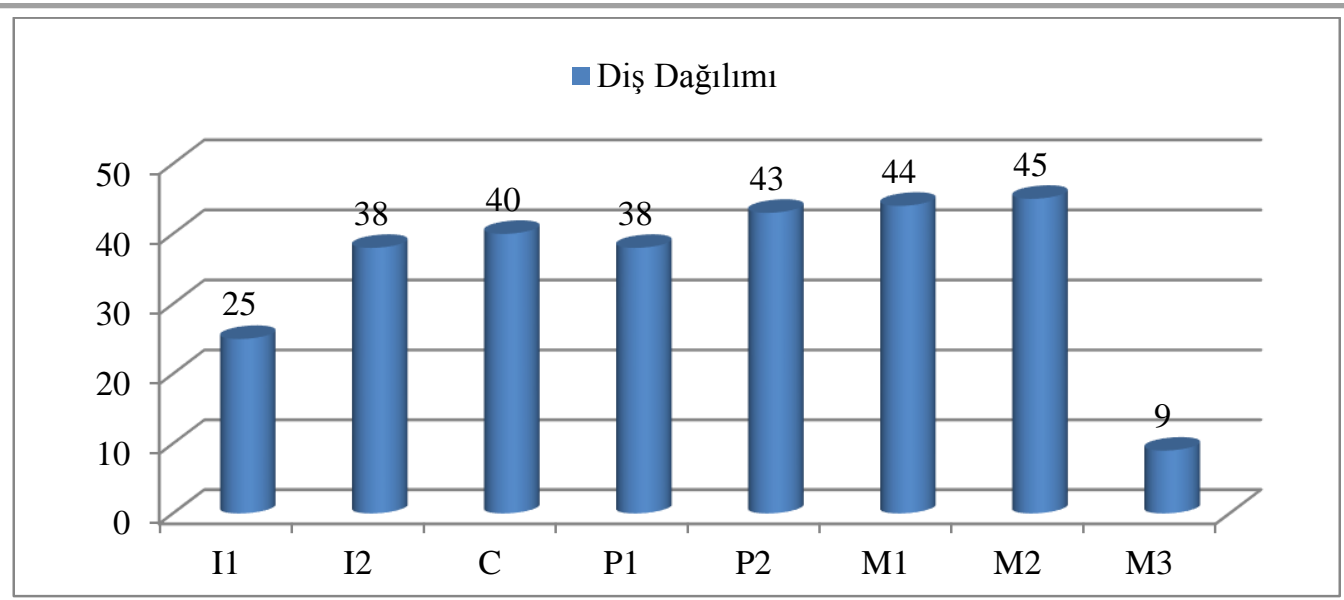

Grafik 3. Gümüş Tümülüsü Toplumunun Diş Dağılımı

Gümüş Tümülüsü toplumuna ait dişlerde var olan patolojiler; diş çürügüü (Buikstra ve Ubelaker,1994; Caselitz,1998), diş taşı (Brothwell,1981), aşınma (Brothwell,1981; Ubelaker,1978), alveol kemik kaybı (Brothwell,1981), apse (Brothwell,1981) incelenmiştir. Antemortem diş kaybı var/yok olarak forma işlenmiştir. Dişlerin enamel tabakalarında tahribatlar olduğu için dişler hipoplasya açısından değerlendirilememiştir. Dişler üzerinde görülen patolojiler diş gruplarına göre incelenmiştir.

Diş Çürüğü; Diş çürüğü, antik dönem toplumu insanlarında diğer diş patolojilerine oranla en sık karşımıza çıkan patolojik oluşumlardır. Diş çürügünün oluşmasında birçok faktör etkilidir. $\mathrm{Bu}$ faktörler arasında ağız hijyeni, ağız ekolojisi, beslenme yapısı ve besin hazırlama teknikleri sayılabilir. Diş çürügü beslenmeyle yakından ilişkilidir ve antik dönem toplumlarının yaşam biçimlerinin ve sağlık yapılarının aydınlatılmasında büyük rol oynar. Özbek (2015), diş çürüğünün oluşumunda unlu ve karbonhidratlı besinlerin etkili olduğunu ve beslenmelerinde et, balık gibi protein ağırlıklı olan toplumlarda diş çürügünün daha az görüldüğünü vurgulamaktadır. Neolitik devrimle birlikte artış gösteren diş çürüğü araştırmacılar tarafından uygarlık hastalığı olarak da tanımlanmaktadır (Uzel, vd.1987).

Gümüş Tümülüsü toplumu diş çürükleri Buikstra ve Ubelaker,1994; Caselitz,1998 geliştirmiş olduğu yöntem kullanılarak incelenmiştir. Buna göre çürükler; 1: Occlusyal Yüzey; 2: İnterproksimal Yüzey; 3: Düz Yüzey (Buccal ve lingual yüzey); 4:Cervical Çürükler (CEJ); 5: Kök Çürükleri; 6: Geniş Çürükler; 7: Diş tacının tamamen yok olduğu pulpaya inen çürükler olarak sınıflandırılmıştır. $\mathrm{Bu}$ doğrultuda yapılan incelemeler sonucunda Gümüş Tümülüsü toplumunda düzeltilmemiş diş çürüğü \%3,52 olarak bulunmuşstur (Tablo 1).

Tablo 1: Gümüş Tümülüsü Diş Çürügü Dağılımı

\begin{tabular}{cccccccccc}
\hline & \multicolumn{3}{c}{ Alt Çene } & \multicolumn{4}{c}{ Üst Çene } & \multicolumn{3}{c}{ Toplam } \\
\hline & B & G & \% & B & G & \% & B & G & \% \\
I1 & 13 & 0 & 0 & 12 & 0 & 0 & 25 & 0 & 0 \\
I2 & 22 & 0 & 0 & 16 & 0 & 0 & 38 & 0 & 0 \\
C & 19 & 0 & 0 & 19 & 0 & 0 & 38 & 0 & 0 \\
P1 & 19 & 0 & 0 & 16 & 0 & 0 & 35 & 0 & 0 \\
P2 & 19 & 0 & 0 & 18 & 0 & 0 & 37 & 0 & 0 \\
M1 & 16 & 0 & 0 & 18 & 5 & 28 & 34 & 5 & 14,7 \\
M2 & 25 & 2 & 8 & 14 & 1 & 7,1 & 39 & 3 & 7,69 \\
M3 & 7 & 1 & 14,28 & 2 & 0 & 0 & 9 & 1 & 11,11 \\
Toplam & 140 & 3 & $\mathbf{2 , 1 4}$ & 115 & 6 & $\mathbf{5 , 2}$ & 255 & 9 & $\mathbf{3 , 5 2}$ \\
\hline
\end{tabular}


Çürük oranı alt çenede $\% 2,14$ iken, üst çenede $\% 5,2$ olarak tespit edilmiştir. Diş tiplerine göre çürük dağılımına bakıldığında ise çürük oranının \%14,7 oranla en çok birinci molarda olduğu görülmektedir. Toplumda ön dişlerde çürüğe rastlanılmamıştır. Yapılan çalışmalar arka dişlerin çürüğe daha çok maruz kaldığını göstermektedir. Arka dişlerin oklusyal yüzeylerinin morfolojik yapısı (tüberküllerin arasında yer alan fissur ve çukurlukların varlığı) yetersiz ağız hijyeni olması durumunda çürük görülme olasılığını arttırmaktadır. Gümüş Tümülüsü toplumunda da bu durum geçerliliğini korumaktadır. Gümüş Tümülüsü toplumunda kadın bireylerde diş çürüğü oranı \%4,76 (126/6) iken, erkek bireylerde \%1,69 (59/1), çocuklarda ise \%5,26 (38/2) olarak tespit edilmiştir (Resim 4). Adölesan bireyin dişlerinde diş çürügüne rastlanmamıştır. Toplum genelinde çürüklerin çoğunlukla gözlemlendiği yüzeyler ise interproksimal yüzeydir. Gümüş Tümülüsü toplumunda pulpaya inen çürük gözlenmemiştir.

Diş Taşı; Gümüş Tümülüsü toplumu bireylerine ait 271 diş, diş taşı oluşumu açısından incelenmiştir. Pulpaya inen aşınma ve çürüğe rastlanılan dişler ve kırık dişler çalışma dışı bırakılmıştır. Gümüş Tümülüsü toplumunun diş taşı dağılımının belirlenmesinde Brothwell (1981)'in geliştirmiş olduğu yöntem dikkate alınmıştır. Buna göre diş taşı birikimleri 0:Diş taşı yok,1: Az, 2:Orta, 3: İleri olarak derecelendirilmiştir. Yapılan incelemeler sonucunda toplumun diş diş taşı oranı $\% 17,34$ olarak tespit edilmiştir (Resim 5). Alt çenede diş taşı oranı \%25,85 iken, üst çenede diş taşı oranı $\% 7,25$ olarak belirlenmiştir. Alt çenede diş taşı oranı daha yüksektir. Diş gruplarına göre diş taş1 oranlarına bakıldığında ise \%52,63 oranla en fazla diş taşına rastlanılan diş grubu birinci incisive olduğu görülmektedir. Ön dişlerde arka dişlere oranla daha yüksek oranda diş taşı birikimi gözlenmiştir (Tablo 2).

Toplumdaki az dereceli diş taşı oranı $\% 10,7$, orta dereceli diş taşı oranı $\% 2,95$, ileri dereceli diş taşı oranı ise $\% 3,69$ olarak tespit edilmiştir.

Tablo 2. Gümüş Tümülüsü Diş Taşı Dağılımı

\begin{tabular}{cccccccccc}
\hline & \multicolumn{3}{c}{ Alt Çene } & \multicolumn{3}{c}{ Üst Çene } & \multicolumn{3}{c}{ Toplam } \\
\hline & B & G & \% & B & G & \% & B & G & \% \\
I1 & 12 & 8 & 66,66 & 7 & 2 & 28,57 & 19 & 10 & 52,63 \\
I2 & 22 & 12 & 54,54 & 16 & 2 & 12,5 & 38 & 14 & 36,84 \\
C & 21 & 6 & 28,57 & 19 & 0 & 0 & 40 & 6 & 15 \\
P1 & 21 & 3 & 14,28 & 17 & 0 & 0 & 38 & 3 & 7,89 \\
P2 & 20 & 4 & 20 & 23 & 1 & 4,34 & 43 & 5 & 11,62 \\
M1 & 20 & 1 & 5 & 22 & 2 & 9,09 & 42 & 3 & 7,14 \\
M2 & 24 & 4 & 16,66 & 18 & 2 & 11,11 & 42 & 6 & 14,28 \\
M3 & 7 & 0 & 0 & 2 & 0 & 0 & 9 & 0 & 0 \\
Toplam & 147 & 38 & $\mathbf{2 5 , 8 5}$ & 124 & 9 & $\mathbf{7 , 2 5}$ & 271 & 47 & $\mathbf{1 7 , 3 4}$ \\
\hline
\end{tabular}

Diş Aşınması; Besinlerin çiğnenmesi sırasında fiziksel ve fizyolojik etkilerin sert diş minesi üzerinde oluşturduğu yıkım olarak tanımlanan aşınma, Eski Anadolu toplumlarında en sık görülen patolojik olgulardan biridir. Aşınma, dişlerin kontak yüzeylerinin birbiriyle teması sonucunda oluşabileceği gibi besin hazırlama teknikleri de neden olmaktadır. Antik dönem toplumlarında aşınmaların en büyük nedenleri arasında besinlerin öğütülmesi sırasında yiyeceklerin içerisine taş, kum gibi bir takım sert partiküllerin karışması sayılabilir. Ayrıca dişlerin ip eğrilmesi, ağ yapımı ya da deri işlenmesi sırasında 3. el olarak kullanılması dişlerin aşınmasına neden olan etmenler arasındadır. Gümüş Tümülüsü toplumunda aşınma derecelerinin belirlenebilmesi için her bir diş gurubuna ait diş aşınma dereceleri toplanarak ortalama değerleri alınmıştır (Buikstra ve Ubelaker,1994). Buna göre toplumdaki dişlerin aşınma değeri 3,63 olarak bulunmuştur (Resim 6) (Tablo 3). 
Tablo 3: Gümüş Tümülüsü Diş Aşınma Değeri

\begin{tabular}{|c|l|l|l|l|l|l|l|l|l|}
\hline & \multicolumn{3}{|c}{ ALT ÇENE } & \multicolumn{3}{c|}{ ÜST ÇENE } & \multicolumn{3}{c}{ GENEL } \\
\hline $\begin{array}{c}\text { DİŞ } \\
\text { GRUBU }\end{array}$ & N & PUAN & ORT & N & PUAN & ORT & N & PUAN & ORT \\
\hline I1 & 13 & 41 & 3,15 & 12 & 46 & 3,83 & 25 & 87 & 3,48 \\
\hline I2 & 22 & 74 & 3,36 & 16 & 62 & 3,87 & 38 & 136 & 3,57 \\
\hline C & 21 & 80 & 3,8 & 19 & 62 & 3,26 & 40 & 142 & 3,55 \\
\hline P1 & 21 & 82 & 3,9 & 17 & 68 & 4 & 38 & 150 & 3,94 \\
\hline P2 & 20 & 84 & 4,2 & 23 & 99 & 4,3 & 43 & 183 & 4,25 \\
\hline M1 & 21 & 70 & 3,33 & 23 & 83 & 3,6 & 44 & 153 & 3,47 \\
\hline M2 & 28 & 93 & 3,32 & 17 & 49 & 2,88 & 45 & 142 & 3,15 \\
\hline M3 & 7 & 28 & 4 & 2 & 4 & 2 & 9 & 32 & 3,55 \\
\hline TOPLAM & $\mathbf{1 5 3}$ & $\mathbf{5 5 2}$ & $\mathbf{3 , 6}$ & $\mathbf{1 2 9}$ & $\mathbf{4 7 3}$ & $\mathbf{3 , 6 6}$ & $\mathbf{2 8 2}$ & $\mathbf{1 0 2 5}$ & $\mathbf{3 , 6 3}$ \\
\hline
\end{tabular}

Gümüş Tümülüsü Toplumunun dişleri aşınma dereceleri açısından incelendiğinde en yüksek oranın \%18,43 ile 4.derece olduğu görülmektedir. Toplumdaki diş aşınma oranı ise \%78,02'dir. 1 . Derece aşınma tablosunda "Aşınma Yok" olarak tanımlanmaktadır. Buna göre aşınma görülmeyen dişlerin oranı ise \%21,98' dir (Tablo 4).

Tablo 4: Gümüş Tümülüsü Diş Aşınma Dereceleri

\begin{tabular}{ccc}
\hline $\begin{array}{c}\text { AŞINMA } \\
\text { DERECESI }\end{array}$ & TOPLAM & $\%$ \\
\hline $\mathbf{1}$ & 62 & 21,98 \\
$\mathbf{2}$ & 11 & 3,9 \\
$\mathbf{2 +}$ & 4 & 1,42 \\
$\mathbf{3}$ & 37 & 13,12 \\
$\mathbf{3 +}$ & 9 & 3,2 \\
$\mathbf{4}$ & 52 & 18,43 \\
$\mathbf{4 +}$ & 5 & 1,77 \\
$\mathbf{5}$ & 35 & 12,41 \\
$\mathbf{5 +}$ & 9 & 3,2 \\
$\mathbf{5 + +}$ & 16 & 5,67 \\
$\mathbf{6}$ & 30 & 10,64 \\
$\mathbf{7}$ & 9 & 3,2 \\
$\mathbf{8}$ & 3 & 1,06 \\
TOPLAM & $\mathbf{2 8 2}$ & $\mathbf{1 0 0}$ \\
\hline
\end{tabular}

Gümüş Tümülüsü toplumunda pulpaya inen aşınma oranlarına bakıldığında ise $\% 11,7$ olarak bulunmuştur. Pulpaya inen aşınma oranı alt çenede $\% 9,15$ iken, üst çenede ise $\% 14,72$ olarak tespit edilmiştir. Pulpaya inen aşınma oranı alt çene sağ tarafta \% 7,79 iken, sol tarafta \%10,52 olarak belirlenmiştir. Üst çeneye bakıldığında ise sağ taraftaki pulpaya inen aşınma oranı $\% 12,3$, sol taraftaki oran ise $\% 17,18$ 'dir. Pulpaya inen aşınma oranı diş gruplanı açısından incelendiğinde ise ön grup dişlerde pulpaya inen aşınma oranı arka dişlere oranla daha düşük değerlere sahip olduğu görülmektedir (Tablo 5). Gümüş Tümülüsü toplumunda diş aşınmalarının nedeninin beslenme tarzına dayalı olduğu düşünülmektedir. Dişlerin 3. el olarak kullanıldığına dair herhangi bir belirtiye rastlanılmamıştır. $\mathrm{Bu}$ oran kadın bireylerde \%10,79 iken erkek bireylerde ise \%24,65 olarak bulunmuştur. Erkek bireylerde pulpaya inen aşınmanın daha yüksek olduğu görülmektedir. 
Tablo 5: Pulpaya İnen Aşınma Oranı

\begin{tabular}{|c|c|c|c|c|c|c|c|c|c|c|c|c|c|c|c|c|c|c|}
\hline \multirow{3}{*}{$\begin{array}{c}\text { Diş } \\
\text { Grubu }\end{array}$} & \multicolumn{9}{|c|}{ ALT ÇENE } & \multicolumn{9}{|c|}{ ÜST ÇENE } \\
\hline & \multicolumn{3}{|c|}{$\mathrm{R}$} & \multicolumn{3}{|c|}{$\mathrm{L}$} & \multicolumn{3}{|c|}{ TOPLAM } & \multicolumn{3}{|c|}{$\mathrm{R}$} & \multicolumn{3}{|c|}{$\mathrm{L}$} & \multicolumn{3}{|c|}{ TOPLAM } \\
\hline & B & $\bar{G}$ & $\%$ & $\bar{B}$ & $\bar{G}$ & $\%$ & B & G & $\%$ & B & $\mathbf{G}$ & $\%$ & B & $\mathbf{G}$ & $\%$ & B & $\mathbf{G}$ & $\%$ \\
\hline I1 & 7 & 0 & 0 & 6 & 0 & 0 & 13 & 0 & 0 & 6 & 0 & 0 & 6 & 1 & 16,66 & 12 & 1 & 8,33 \\
\hline I2 & 11 & 0 & 0 & 11 & 0 & 0 & 22 & $\mathbf{0}$ & $\mathbf{0}$ & 7 & 2 & 28,57 & 9 & 1 & 11,11 & 16 & 3 & 18,75 \\
\hline $\mathrm{C}$ & 12 & 1 & 8,33 & 9 & 1 & 11 & 21 & 2 & 9,5 & 8 & 1 & 12,5 & 11 & 0 & 0 & 19 & 1 & 5,26 \\
\hline P1 & $\overline{10}$ & 1 & 10 & 11 & 1 & 9,1 & 21 & 2 & 9,5 & 9 & 0 & 0 & 8 & 1 & 12,5 & 17 & 1 & 5 \\
\hline $\mathbf{P 2}$ & 9 & 0 & 0 & 11 & 1 & 9,1 & 20 & 1 & 5 & 13 & 2 & 15,38 & 10 & 2 & 20 & 23 & 4 & 17,39 \\
\hline M1 & 11 & 2 & 18,18 & 10 & 3 & 30 & 21 & 5 & 24 & 13 & 3 & 23,07 & 10 & 3 & 30 & 23 & 6 & 26,08 \\
\hline M2 & 14 & 2 & 14,28 & 14 & 2 & 14 & 28 & 4 & 14 & 9 & 0 & 0 & 8 & 3 & 37,5 & 17 & 3 & 17,64 \\
\hline M3 & 3 & 0 & 0 & 4 & 0 & 0 & 7 & $\mathbf{0}$ & $\mathbf{0}$ & 0 & 0 & 0 & 2 & 0 & 0 & 2 & $\mathbf{0}$ & $\mathbf{0}$ \\
\hline TOPLAM & $\overline{77}$ & 6 & 7,79 & 76 & 8 & 10,52 & 153 & 14 & 9,2 & 65 & 8 & 12,3 & 64 & 11 & 17,18 & 129 & 19 & 14,72 \\
\hline
\end{tabular}

Antemortem Diş Kaybı; Eski Anadolu toplumlarının ağız sağlığını en iyi yansıtan patolojik olgulardan biri ölüm öncesi diş kaybı olarak tanımlanan antemortem diş kaybıdır. Antemortem diş kaybının nedenleri arasında ileri derece aşınma, çürük, ileri derece alveol kaybı ve periyodontal (diş eti hastalıkları) sayılabilir. Gümüş Tümülüsü toplumunda antemortem diş kaybı oranı \% 6,2 olarak tespit edilmiştir (Resim 7). Bu oran kadın bireylerde \%5,31 iken, erkek bireylerde \%7,84 olarak belirlenmiştir (Tablo 6).

Antemortem diş kaybının en sık görüldüğü diş grubu \%21 oranla birinci molardır. Alt çenede antemortem diş kaybının en çok görüldüğü diş birinci molar (\%26) iken, üst çenede antemortem diş kaybının en çok görüldüğü diş grubu ise \%25 oranla üçüncü molar olmuştur. Antemortem diş kayıpları arasında ileri derece çürük, ileri derece aşınma, ileri derece alveol kaybı ve apse yer almaktadır. Gümüş Tümülüsü toplumunda çürük oluşumu en çok arka dişleri özellikle de birinci moları etkilemiştir. Aynı şekilde apse oluşumu görülme sıklı̆̆ birinci molarda en yüksektir. Dolayısıyla antemortem diş kaybının en sık birinci molarda görülmesi kaçınılmazdır.

Tablo 6: Gümüş Tümülüsü Antemortem Diş Kaybı Dağılımı

\begin{tabular}{lccccccccc}
\hline & \multicolumn{3}{c}{ ALT ÇENE } & \multicolumn{3}{c}{ ÜST ÇENE } & \multicolumn{4}{c}{ TOPLAM } \\
\hline & B & G & \% & B & G & \% & B & G & $\%$ \\
I1 & 22 & 2 & 9,1 & 18 & 0 & 0 & 40 & 2 & 5 \\
I2 & 22 & 0 & 0 & 17 & 0 & 0 & 39 & 0 & 0 \\
C & 22 & 0 & 0 & 17 & 0 & 0 & 39 & 0 & 0 \\
P1 & 22 & 0 & 0 & 17 & 2 & 12 & 39 & 2 & 5,1 \\
P2 & 22 & 0 & 0 & 18 & 1 & 5,6 & 40 & 1 & 2,5 \\
M1 & 23 & 6 & 26 & 15 & 2 & 13 & 38 & 8 & 21 \\
M2 & 21 & 0 & 0 & 15 & 2 & 13 & 36 & 2 & 5,6 \\
M3 & 11 & 1 & 9,1 & 8 & 2 & 25 & 19 & 3 & 16 \\
TOPLAM & $\mathbf{1 6 5}$ & $\mathbf{9}$ & $\mathbf{5 , 5}$ & $\mathbf{1 2 5}$ & $\mathbf{9}$ & $\mathbf{7 , 2}$ & $\mathbf{2 9 0}$ & $\mathbf{1 8}$ & $\mathbf{6 , 2}$ \\
\hline
\end{tabular}

Apse: Periyodontal hastalıkların neden olduğu apse Gümüş Tümülüsü toplumunda \%1,4 oranında tespit edilmiştir. Apse oranı kadın bireylerde \%1,61, erkek bireylerde ise \%1,06 oranında gözlenmiştir. Apse oranı alt çenede $\% 1,89$ iken üst çenede $\% 0,81$ oranında olduğu görülmüştür (Resim 8). Apse oluşumu diş grupları açısından incelendiğinde alt çenede sadece birinci molarda apse oluşumu gözlenirken, üst çenede 1 caninde apse oluşumuna rastlanmıştır. Alt ve üst çene birlikte değerlendirildiğinde apse oluşumunun en yüksek \%9,67 oranla birinci molar olduğu görülmektedir (Tablo 7).

\section{Turkish Studies - Social Sciences}

Volume 14 Issue 4, 2019 
Tablo 7: Gümüş Tümülüsü Apse Dağılımı

\begin{tabular}{cccccccccc}
\hline & \multicolumn{3}{c}{ ALT ÇENE } & \multicolumn{3}{c}{ ÜST ÇENE } & \multicolumn{3}{c}{ TOPLAM } \\
\hline & B & G & \% & B & G & \% & B & G & \% \\
I1 & 20 & 0 & 0 & 18 & 0 & 0 & 38 & 0 & 0 \\
I2 & 24 & 0 & 0 & 18 & 0 & 0 & 42 & 0 & 0 \\
C & 22 & 0 & 0 & 18 & 1 & 5,55 & 40 & 1 & 2,5 \\
P1 & 22 & 0 & 0 & 16 & 0 & 0 & 38 & 0 & 0 \\
P2 & 22 & 0 & 0 & 18 & 0 & 0 & 40 & 0 & 0 \\
M1 & 16 & 3 & 18,75 & 15 & 0 & 0 & 31 & 3 & 9,67 \\
M2 & 22 & 0 & 0 & 13 & 0 & 0 & 35 & 0 & 0 \\
M3 & 10 & 0 & 0 & 6 & 0 & 0 & 16 & 0 & 0 \\
& 158 & 3 & 1,89 & 122 & 1 & 0,81 & 280 & 4 & $\mathbf{1 , 4}$ \\
\hline
\end{tabular}

Alveol Kaybı: Mikroorganizmalar nedeniyle dişetinde oluşan iltihap alveol kemikte yıkıma neden olur (Brothwell, 1981). Alveol kemik kaybına neden olan etmenler arasında diş taşı, diş aşınması, beslenme bozukluğu, ağız ve diş bakımının yetersiz olması sayılabilir (Hillson,2008;Özbek,2015). Toplumdaki alveol kaybı dağılımı Brothwell'in (1981) geliştirmiş olduğu yönteme göre belirlenmiştir. Buna göre 0: Alveol kaybı yok, 1: Alveol kaybı az, 2: Alveol kaybı orta, 3: Alveol kaybı ileri olarak sınıflandırılmıştır. Toplumun alveol kaybı oranını belirlemek için çeneler üzerindeki alveoller dikkate alınmıştır. Buna göre toplam 212 alveolun 130'unda \%61,32 oranında alveol kaybı tespit edilmiştir (Resim 9). Alveol kaybı oranı kadınlarda \%60,16 iken, erkek bireylerde \%62,76'dır. Toplumdaki alveol kaybı dereceleri de ayrıca değerlendirilmiştir. Buna göre var olan alveol kaybı oranları az (1), orta (2) ve ileri (3) olarak kaydedilmiştir. Az dereceli alveol kaybı oranı gözlenmezken, orta dereceli alveol kaybı \%17,7, ileri dereceli alveol kaybı ise \%82,3 olarak tespit edilmiştir.

\section{Sonuç ve Tartışma}

Gümüş Tümülüsü Toplumuna ait toplam 282 diş paleopatolojik açıdan incelenmiştir. İncelenen dişlerin 139'u kadın, 73'ü erkek, 38'i çocuk, 15' i ise adölesan bireye ait olduğu belirlenmiştir. Dişlerin 17'si izoledir. Toplumda diş çürügü oran1 \%3,52, antemortem diş kaybı oranı $\%$ 6,2, apse oranı ise \%1,4 olarak tespit edilmiştir. Gümüş Tümülüsü bireylerinin dişlerinde görülen patolojiler cinsiyetler açısından değerlendirilmiştir (Tablo 8). Buna göre diş çürüğü kadın bireylerde $\% 4,76$ iken erkek bireylerde \%1,7 olarak tespit edilmiştir.

Tablo 8: Diş Patolojilerinin Cinsiyetler Arası Dă̆glımı

\begin{tabular}{lcccccc}
\hline & \multicolumn{3}{c}{ KADIN } & \multicolumn{3}{c}{ ERKEK } \\
\hline & B & G & \% & B & G & $\%$ \\
DİŞ ÇÜRÜĞÜ & 126 & 6 & 4,76 & 59 & 1 & 1,7 \\
$\begin{array}{l}\text { ALVEOL } \\
\text { KAYBI }\end{array}$ & 118 & 71 & 60,16 & 94 & 59 & 63 \\
$\begin{array}{l}\text { ANTEMORTEM } \\
\text { DIŞ KAYBI }\end{array}$ & 188 & 10 & 5,31 & 102 & 8 & 7,8 \\
DIŞ TAŞI & 130 & 18 & 13,84 & 71 & 27 & 38 \\
APSE & 186 & 3 & 1,61 & 94 & 1 & 1,1 \\
\hline
\end{tabular}

Araştırmacılar diş çürüğü görülme sıklığının cinsiyetler arasında farklı olduğunu ve kadınların diş çürügünden daha fazla etkilendiğini belirtmektedir (Larsen vd,1991;Vanna,2007). Kadın bireylerde diş çürügünün daha yüksek görülmesinin nedenleri arasında kız çocuklarında dişlerin daha erken sürmesi, cinsiyetler arasındaki fiziksel ve davranışsal farklılıklar ve gebeliğin diş sağlığını olumsuz yönde etkilemesi gibi nedenler gösterilmektedir (Larsen vd,1991;194). Ayrıca kadınlarda görülen hormonal değişimlerin de diş çürüğü oluşmasında etkili olduğu belirtilmiştir (Vanna,2007). Gümüş 
Tümülüsü toplumunda kadınlarda diş çürüğü oranının yüksek olmasında bu faktörlerin etkili olabileceği düşünülmektedir. Alveol Kaybı oranı kadın bireylerde \%60,16, erkek bireylerde ise \%63 olarak belirlenmiştir. Antemortem diş kaybı ve diş taşı oranları erkek bireylerde daha yüksek olduğu görülmektedir. Apse oranı ise her iki cinsiyette de yakın değerlerdedir.

Gümüş Tümülüsü toplumunda diş aşınma oranı \%78,02 gibi yüksek bir orana sahiptir. Diş aşınma derecesi dağılımına bakıldığında en yüksek $(\% 18,43) 4$. derece (ileri) olduğu görülmektedir. Ayrıca pulpaya inen aşınma oranın yüksek olması besinlerin içine sert partiküllerin karışmış olabileceğini düşündürmektedir. Yoğun tarım faaliyetlerinin yapıldığı eski Anadolu toplumlarında diş çürüğü oranının daha yüksek çıktığı bilinmektedir. Gümüş Tümülüsü toplumunun diş çürügünün düşük oranda çıkması toplumda yoğun bir tarım faaliyetinin olmadığını göstermektedir. Apsenin nedenleri arasında diş çürüğü ve ileri derece aşınmanın neden olduğu bilinmektedir. Gümüş Tümülüsü toplumunda çürük oranı düşük değerde iken, aşınma oranının \%78,02 gibi yüksek oranda olması apsenin nedenleri arasında aşınmanın da olabileceğini göstermektedir. Gümüş Tümülüsü toplumunda ileri derece alveol kaybına sahip bireylerin ileri erişkin bireyler olduğu görülmektedir. Dolayısıyla Gümüş Tümülüsü'ndeki alveol kaybının yaşla doğru orantılı olarak arttığı söylenebilir. Antemortem diş kaybının nedenleri arasında çürük, ileri derece aşınma, diş taşı ve alveol kaybı sayılabilir. Gümüş Tümülüsü toplumunda çürük oranı az olmasına rağmen alveol kaybı ve aşınma oranın yüksek olduğu düşünülürse antemortem diş kaybının nedenleri arasında alveol kaybı ve aşınma gösterilebilir. Toplumdaki antemortem diş kaybı görülen bireylerin yaş dağılımlarına bakıldığında ise ileri erişkin bireylerin çoğunlukta olduğu tespit edilmiştir.

Gümüş Tümülüsü toplumuna ait diş patolojileri çağdaşı olan diğer eski Anadolu toplumlarıyla karşılaştırılmıştır. Gümüş Tümülüsü toplumu diş çürügü oranı çağdaş1 olan toplumlarla karşılaştırıldığında Laodikeia (Şimşek,2011) toplumundan sonra en düşük değere sahip olduğu görülmektedir. Apse oranı açısından bakıldığında Amasya (Akbacak ve Gözlük Kırmızıoğlu, 2018), Helenistik Dönem Smyrna Agorası (Yaşar vd,2007), Roma Dönemi Domaniç (Erkman vd,2017), Bizans Dönemi Smyrna Agoras1 (Gözlük vd,2005) toplumlarıyla benzer orana sahip olduğu görülmektedir (Tablo 9). Gümüş Tümülüsü toplumunun diş taşı oranı ise Smyrna Agorası, Panaztepe toplumlarıyla yakın değerlerdedir (Tablo 9). Gümüş Tümülüsü apse oranı, Datça/Burgaz (Karaöz Arıhan vd,2009), Amasya, Kyzikos (Gözlük Kırmızıoğlu vd,2008), Çiçekdağı (Alkan vd,2013), toplumlarından yüksek orana sahipken, Milas/Gümüşlük (Sağır vd,2009), Laodikeia, Arslantepe (Uzel vd,1987), Dara Antik Kenti (Şarbak,2017), Kirazlıdere (Suata Alpaslan ve Uz,2017), Alanya Kalesi (Üstündağ ve Demirel,2009), İasos (Yılmaz Usta,2013), Zeytinli Ada (Bıçak ve Suata Alpaslan,2015), Mardin/Midyat (Acar,2018), toplumlarından ise düşük değerlere sahip olduğu görülmektedir (Tablo 9). Gümüş Tümülüsü toplumunda alveol kaybı oranı ise, Dara Antik Kenti ile benzerlik gösterirken Çicekdağı, Alanya Kalesi, Smyrna Agorası, Datça-Burgaz, Parion (Yavuz vd,2012), Laodikeia, Kirazlıdere, Amasya, toplumlarından yüksek orana sahiptir (Tablo 9). Kyzikos ve İasos toplumlarından ise düşük orana sahip olduğu görülmektedir (Tablo 9). Bizans Gümüş Tümülüsü toplumunda aşınma derecesi 4 olarak tespit edilmiştir. $\mathrm{Bu}$ değer çağdaşı olan toplumlarla karşılaştırıldığında ekonomisi tarım ve tarım/hayvancılık olan toplumlarla benzerlik gösterdiği görülmektedir. Sonuç olarak bakıldığında Gümüş Tümülüsü toplumunun beslenmesinde tarım ürünlerinin yanı sıra proteinlerin de yer aldığı söylenebilir. Ağız ve diş sağlığı hakkında önemli veriler sunan diş çürügü ve apse oranın düşük değerde olması ise toplumun diş sağlığı ve sosyo ekonomik düzeylerinin iyi olduğu düşünülmektedir. 
Tablo 9: Eski Anadolu Toplumlarında Diş Hastalıklarının Görülme Oranları

\begin{tabular}{|c|c|c|c|c|c|c|c|c|c|}
\hline Toplum & Dönem & Araştırmacı & $\begin{array}{c}\text { Diş } \\
\text { Çürüğü } \\
\%\end{array}$ & Apse & $\begin{array}{l}\text { Diş } \\
\text { Taşı } \\
\%\end{array}$ & $\begin{array}{c}\text { Alveol } \\
\text { Kaybı } \\
\%\end{array}$ & $\begin{array}{l}\text { Antemortem } \\
\text { Diş Kaybı \% }\end{array}$ & $\begin{array}{c}\text { Hipoplasya } \\
\%\end{array}$ & $\begin{array}{r}\text { Aşınma } \\
\text { (Derece) }\end{array}$ \\
\hline Milas/Gümüşlük & \begin{tabular}{|l|} 
Klasik - \\
Helenistik
\end{tabular} & Sağır vd,2009 & 10,42 & 13,57 & 65 & - & 20 & 41,25 & - \\
\hline Datça/Burgaz & Helenistik & $\begin{array}{l}\text { Karaöz Arıhan } \\
\text { vd, } 2009 \\
\end{array}$ & 20 & 11,11 & 4,16 & 25 & 33,82 & 0 & $3 \& 4$ \\
\hline Parion & Helenistik,Roma & $\begin{array}{l}\text { Yavuz vd, } \\
2012 \\
\end{array}$ & - & 5,06 & - & 31,25 & 5,4 & - & $4+$ \\
\hline Smyrna Agorası & Helenistik,Roma & Yaşar vd,2007 & 4,46 & 1,63 & 16,96 & 33,3 & 7,61 & 11,7 & - \\
\hline Laodikeia & Roma & Şimşek,2011 & 2,62 & 3,8 & 31,23 & 50,61 & 7,78 & 11,36 & $4 \& 3$ \\
\hline Panaztepe & Roma & Güleç vd,1998 & 11,11 & - & 14,76 & - & 11,11 & 22,73 & - \\
\hline Mardin/Midyat & Roma & Acar,2018 & 6,19 & 9,29 & - & - & 42,95 & - & - \\
\hline Amasya & Roma & $\begin{array}{l}\text { Akbacak ve } \\
\text { Gözlük } \\
\text { Kırmızıŏlu, } \\
2018 \\
\end{array}$ & 4,65 & 1,35 & 2,91 & 36,3 & 6,28 & 4,65 & 3 \\
\hline Mardin/Midyat & Roma & Acar,2018 & 6,19 & 9,29 & - & - & 42,95 & - & - \\
\hline Domaniç & Roma & $\begin{array}{l}\text { Erkman } \\
\text { vd,2017 }\end{array}$ & 19,57 & 2,78 & 35,38 & 67,33 & 13,39 & 17,19 & $4+\& 5$ \\
\hline Arslantepe & Geç Roma & Uzel vd, 1987 & 9,52 & - & 80 & - & 14,02 & - & - \\
\hline Dara & Geç Roma & Şarbak,2017 & 13,63 & 3,71 & 68,32 & 69,36 & 7,15 & 34,48 & 3 \\
\hline Kyzikos & M.S.II.yy & \begin{tabular}{|l|} 
Gözlük \\
Kırmızıoğlu \\
vd,2008 \\
\end{tabular} & 7,76 & 0 & 5,31 & 100 & 3,79 & 56,73 & 2 \\
\hline Kirazlıdere & Erken Bizans & $\begin{array}{l}\text { Suata } \\
\text { Alpaslan ve } \\
\text { Uz (2017), }\end{array}$ & 7,8 & 9,21 & 67,37 & 56,81 & 35,23 & 38,29 & 4 \\
\hline Çiçekdağı & Erken Bizans & Alkan vd,2013 & 5,66 & 0 & 1,88 & 33 & 9,09 & 22,64 & 4 \\
\hline Smyrna Agorası & Bizans & $\begin{array}{l}\text { Gözlük } \\
\text { vd,2005 }\end{array}$ & 4,68 & 1,63 & 16,96 & 33,33 & 7,61 & 11,7 & 4 \\
\hline Alanya Kalesi & Bizans & \begin{tabular}{|l|} 
Üstündağ ve \\
Demirel;2009 \\
\end{tabular} & 12,06 & 2,3 & 29,6 & 35,3 & 2,8 & 39,07 & \\
\hline İasos & Bizans & $\begin{array}{l}\text { Y1lmaz } \\
\text { Usta,2013 }\end{array}$ & 5,38 & 2,1 & 50,8 & 85 & 13,87 & 15,43 & 3 \\
\hline Zeytinli Ada & $\begin{array}{l}\text { Helen-Roma- } \\
\text { Bizans-Osmanlı }\end{array}$ & $\begin{array}{l}\text { Bıçak ve Suata } \\
\text { Alpaslan,2015 }\end{array}$ & 4,9 & 6,61 & 71,07 & 58,42 & 38,27 & 42,64 & 4 \\
\hline Gümüş Tümülüsü & Bizans & $\begin{array}{l}\text { Şarbak,2019 } \\
\text { (Bu Çalışma) }\end{array}$ & 3,52 & 1,4 & 17,34 & 61,32 & 6,2 & & 4 \\
\hline
\end{tabular}




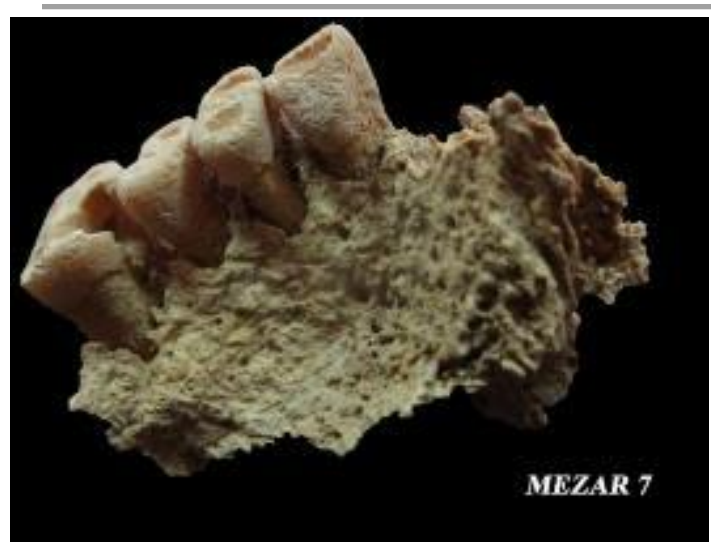

Resim 4. Diş Çürüğüu

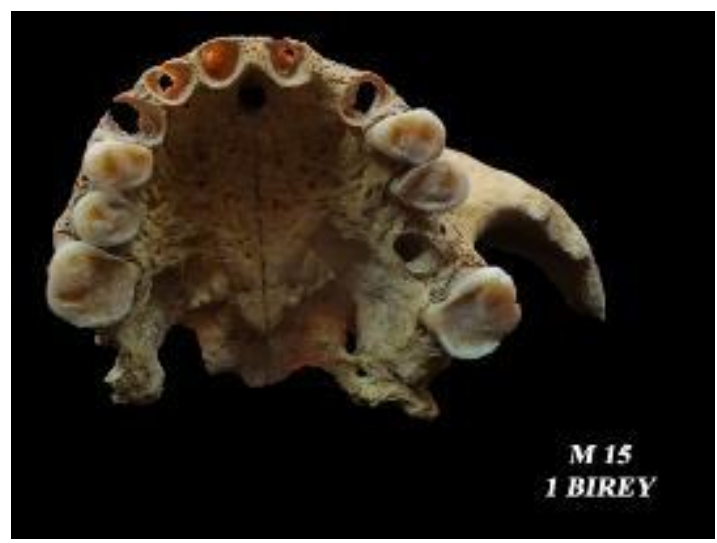

Resim 6. Diş Aşınması

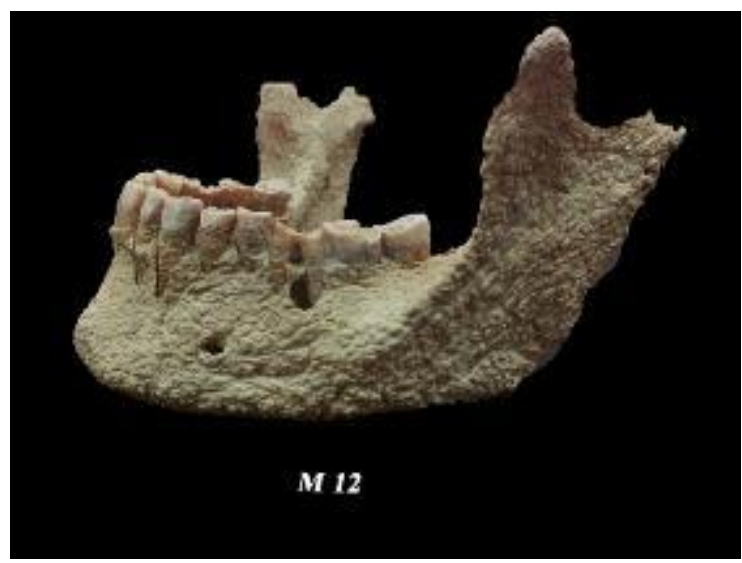

Resim 8. Apse

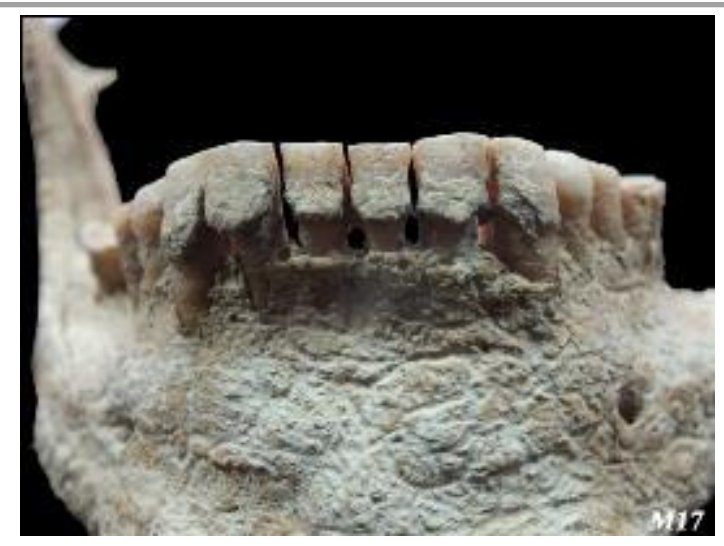

Resim 5. Diş Taşı

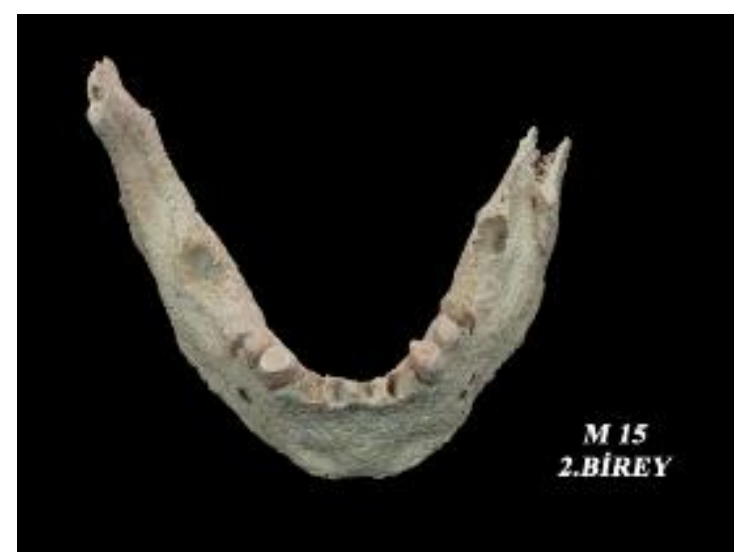

Resim 7. Antemortem Diş Kaybı

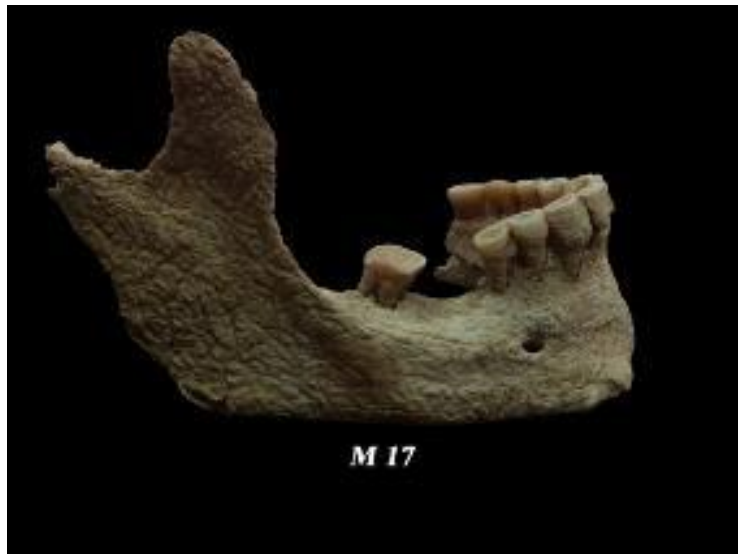

Resim 9. Alveol Kemik Kaybı

\section{KAYNAKÇA}

Acar, A. (2018), "Mardin Midyat Aktaş Mevkii İnsan İskeletlerinde Diş ve Çene Patolojileri”,Mukaddime, 2018, 9(1), 151-172 DOI: 10.19059/mukaddime.353493,151-172.

Akbacak, H. Ve Gözlük Kırmızığlu, P. (2018), “Amasya Roma Dönemi İnsanları”, Hitit Üniversitesi Sosyal Bilimler Enstitüsü Dergisi, ANARSAN Sempozyumu Özel Sayıs1, Ekim 2018, Cilt 11 Say1 2 , ss. 1631-1650. 
Alkan, Y., Erkman, A. C., Kaplan, İ. (2014), "Çiçekdağı İskeletlerinin Paleoantropolojik Analizi, 29. Arkeometri Sonuçları Toplantısı, s: 77-82.

Bıçak, S. ve Suata Alpaslan,F. (2015), "Zeytinli Ada İskelet Topluluğunun Diş ve Çene Patolojisi Açısından İncelenmesi ”, Cumhuriyet Üniversitesi Fen Fakültesi Fen Bilimleri Dergisi (CFD), Cilt:36, No: 5 (2015) ISSN: 1300-1949, S.32-46.

Brothwell, D.R. (1981), Digging up Bones, Oxford University Press British Museum (Natural History), London.

Buikstra, J. E., Ubelaker, D. H. (1994), Standards For Data Collection From Human Skeletal Remains, Arkansas Archeological Survey Research Series, No:44.

Caselitz, P. (1998), Caries- Ancient Plaque of Humankind, Kurt W.Alt,Friedrich W. Rösing, Maria Tescler- Nicola (ed), Dental Antropology, Springer- Verlag/Wien, sf, 203-226.

Çırak, M.T., Şarbak, A., Çırak, A. (2017), "Accessory Mental Foramen (Amf) In The Byzantıne Population Of Great Göztepe Tumulus/Safranbolu", Mediterranean Archaeology and Archaeometry, Vol. 17, No 2, (2017), pp. 97-104.

Erkman, A., C., İlbey,S., Gökkurt, S., T. (2017), “Domaniç Anıtsal Tonozlu Mezar İskeletlerinin Ağız ve Diş Sağlığı İle Mine Hipoplazilerinin İncelenmesi”, Kütahya Müzesi 2016 Ylllığı, Sayı IV, Bilgin Kültür Sanat Yayıncılık, Ankara, S.407-426.

Gözlük, P., Durgunlu, Ö., Özdemir, S., Taş̧ıalan, M., Sevim, A. (2005),"Symrna Agoras1 İskeletlerinin Paleoantropolojik Analizi”, 21. Arkeometri Sonuçları Toplantısı, Ankara.

Gözlük Kırmızıŏlu, P., Yaşar,F.,Yiğit,A., Sevim,Erol,A. (2008), "Kyzikos İskeletlerinin Dental Analizi”, 24. Arkeometri Sonuçları Toplantısı, Ankara, s. 139.

Güleç, E., ve Duyar, İ. (1998), "Panaztepe MÖ İkinci Bin ve Roma Dönemi İskeletlerinin Antropolojik Analizi (1985-1990)", Antropoloji, 13, 179-206.

Hillson, S.W., (2008), The current state of dental decay. In: Technique and application in dental anthropology, Irish JD, Nelson G, editors, Cambridge, UK: Cambridge University Press, pp. 111-135.

Kaur, H., Jit, I., (1990), "Age estimation from cortical index of the human clacicle in Northwest Indians." American Journal of Physical Antropology, 83: 297-305.

Karaöz Arıhan,S., Çırak, A., Erkman, A., C. (2009), "Datça/Burgaz İskeletlerinin Paleoantropolojik Analizi”, 25.Arkeometri Sonuçları Toplantısı, 297-310.

Larsen, C.S., Shavit,R., Mark C. Griffin, M.C.(1991), Dental Caries Evidence for Dietary Change: An Archaeological Context, Advances in Dental Anthropology, P. 179-202

Olivier, G. (1969), Practical Anthropology, Illnois: Charles C Thomas Pub.

Özbek, M. (2015), Dişlerle Tarihöncesine Yolculuk, Bilgin Kültür Sanat Yayınları, ISBN: 9786056560149 .

Roberts, C., ve Manchester, K. (2012), The Archaelogy of Disease, Stroud: The History Press, Third Edition,

Sağır, M., Satar, Z., Özer, İ., Güleç,E. (2009), “Gümüşlük- Milas İskeletlerinin Ağız ve Diş Sağlığı”, 25. Arkeometri Sonuçları Toplantısı, S:69,Ankara.

Suata Alpaslan, F. ve Uz, B. (2017), "Kirazlıdere İskelet Topluluğunun Çene ve Diş Patolojisi Açısından İncelenmesi”, CÜ Sosyal Bilimler Dergisi, Aralık 2017, Cilt: 41, Sayı: 2, s.1-19. 
Şarbak, A. (2017), "Dara Geç Roma Dönemi Antik Kenti Toplumunun Ağız ve Diş Sağlığı Üzerine Bir Araştırma", Eurasian Academy of Sciences Eurasian Art \& Humanities Journal, Volume:7,S:10 37

Şimşek, N. (2011), Laodikeia Popülasyonunun Diş ve Çenelerini Paleopatolojik Açıdan İncelenmesi, Ankara Üiversitesi Sosyal Bilimler Enstitüsü,(Basılmamış Doktora Tezi).

Ubelaker, D. H. (1978), Human Skeletal Remains, Smithsonian Institution, Adline Publishering Company, Chicago.

Uzel, İ. Alpagut, B., Kofoğlu, S., (1987), "Arslantepe (Malatya) Geç Roma Dönemi İskeletlerinde Diş Çürüğü, Aşınmalar ve Periodonta1 Hastalıklar", III. Arkeometri Sonuçlan Toplantısı, Ankara. Ss. 31-53.

Üstündağ, H., ve Demirel, A. (2009), “Alanya Kalesi İskelet Topluluğunda Ağız ve Diş Sağlığı”, Hacettepe Üniversitesi Edebiyat Fakültesi Dergisi, 26, 219-234.

Vanna, V. (2007), "Sex and Gender Related Health Status Differences in Ancient and Contemporary Skeletal Populations", Papers from the Institute of Archaeology 18 (2007): 114-147

White, D. T, Black, M. T, Folkens, P. (2012), Human Osteology, Printed in U. S. A. Academic Press

Workshop Of European Anthropologists, (1980), Recommendations for Age and Sex Diagnoses of Skeletons, Journal of Human Evolution, 9: 517-54.

Yaşar, Z., Yiğit, A., Gözlük Kırmızıoğlu,P., Sevim Erol, A. (2007), "Smyrna Agorası İnsanlarının Ağız ve Diş Sağlığı", 23. Arkeometri Sonuçları Toplantısl, 127-140.

Yavuz, A., Y., Özdemir, S., Ürker, K., Sevim Erol, A. (2012), "Parion İskeletlerinin Antropolojik Analizi”, 28.Arkeometri Sonuçları Toplantısı, 69-82.

Yılmaz Usta, N. (2013), "Iasos (Bizans Donemi) Toplumunda Ağız ve Diş Sağlığı”, Antropoloji Dergisi, Sayı:25, sf:117. 